\title{
DANGEROUS LIAISONS: CORRUPTION AND MONEY LAUNDERING IN CONTEMPORARY SOCIETY
}

\author{
Georgi Petrunov ${ }^{1}$
}

DOI: https://doi.org/10.31410/LIMEN.2020.371

\begin{abstract}
The article analyzes the dangerous links between two criminal activities that are widespread in contemporary societies, corruption and money laundering. The spread of both crimes has a serious negative impact on our economies and societies. Moreover, the links between corruption and money laundering contribute to the criminalization of the state itself. The article describes the main characteristics of each criminal activity, focusing on the specific connections between them, and argues for the need of effective integrated counteraction policies.
\end{abstract}

Keywords: Corruption, Money laundering, Politically exposed persons.

\section{INTRODUCTION}

$\mathrm{O}$ ver the past decades, a growing number of studies has identified corruption as one of the main obstacles to economic development. The international community views corruption as a factor that erodes the stability of governments, undermines the democratic principles and foundations of societies, and perpetuates inequalities, poverty and discontent among the people (UNODC, 2018; World Bank, 2018). Corruption is also referred to in the UN Sustainable Development Goals 2030, in Goal 16 and Sub-Goals 3, 4, 5 and 6 (UN, 2015). It is considered a major hindrance to a sustainable socio-economic development and the cause of violence, insecurity and injustice, which is why coordinated efforts are needed to fight it. According to research data (Quintanilla et al., 2018), the cost of corruption across the EU put the loss to GDP as a result between 179 and 950 billion euros per year, and at national level that percentage ranges from $0.76 \%$ of the GDP in the Netherlands to $15 \%$ of GDP in Romania. Today, researchers are convinced that corruption is at the root of many failed states in Africa, Eastern Europe and Asia, in which large-scale corruption cases have made the news around the world (Chaikin \& Sharman, 2009, p. 7).

While corruption causes huge damage to societies and economies, at the same time it generates significant illicit profits for the perpetrators. In order to enter the legal economy without the risk of being detected, the illicit funds must be managed so that their illegal origin is well concealed, i.e. the money has to be laundered. Although the link between criminal activity and money laundering has long been recognized (Levi et al., 2007), it is only recently that researchers have turned their attention to the topic of laundering money received from corruption. This is because money laundering has been mainly associated with drug-related crimes. The issue of corruption as a predicate offense, on the other hand, is not sufficiently studied.

This article aims to expose the dangerous links between corruption and money laundering. The intertwining of the two criminal activities appears to play a key role in the processes of

1 University of National and World Economy, Sofia, Bulgaria, boul.8th December, Bulgaria 
criminalization of the state in modern societies. To effectively counter these processes, policies integrating the fight against corruption and money laundering are needed.

\section{MANIFESTATIONS OF CORRUPTION IN CONTEMPORARY SOCIETY}

Corruption has many faces, and in the following chapters we briefly described some of them.

There is broad consensus in the literature that corruption concerns the public sphere, state and bureaucratic structures (Maltz, 1985; Poole-Robb \& Bailey, 2002), and is understood as the abuse of power for personal gain (Tanzi, 1998). This definition has gained great popularity and is also found in international anti-corruption conventions (for example, in the UN Convention against Corruption, Council of Europe documents, etc.). However, in recent years, more and more attention has been paid to corruption in the private sphere, as its size and negative effects are becoming more significant and cannot be neglected (Argandoña, 2003; Gopinath, 2008; Stoyanov, 2018; Sartor, \& Beamish, 2020).

Corrupt practices take place both at the lowest level and at the highest levels of government. Every act of corruption has negative effects, and the result is illegal gains. The profits from corruption range from small amounts to millions of euros. What may appear as a negligible amount of 5-10 euros, for example, illegally collected by customs officers for letting someone pass border control easily, may in fact be part of systemic corrupt practices which can generate thousands of euros in illegal revenue per day. Such examples show that corruption should not be understood as just a deviant individual behavior, but rather the coordinated joint activities of well-structured organizations.

Like any other human activity, when organizations are engaged in corruption, the scale of operations is much bigger and sustainable over time, unlike any personal act. A number of investigations in Bulgaria have shown that employees at various inspection and control bodies - customs officers, police units, tax officials, traffic agencies, medical commissions, and others - carry out well-coordinated organized corruption activities. Organized corruption can grow quite substantial in scale and scope. In some cases, we have an example of a captured state (Stoyanov \& Gerganov, 2019; Nonchev, 2019), where the employees have gained control over the institutions and use them to charge extra fees in addition to the regulated taxes and fees. In some cases, corrupt officials in these institutions exclude those employees who do not wish to participate in illegal activities.

What is important to grasp is that the problem of corruption concerns the institutional framework, and is independent of the individual or individuals holding certain positions. A person, a group of people or even all employees in an institutional unit can be replaced, and after a short period the newly appointed people will engage in the same corrupt practices.

The profits from corruption often exceed multiple times the official salary received by the corrupt employees. But possessing large amounts of cash is not enough, if the owner cannot freely spend it. A corrupt politically exposed person (PEP) can use a luxury company car, have a huge office, and be in a legitimate power position, overseeing many subordinates, but he/she will not be able to use the illegally obtained millions and would be forced to live in a small apartment until his or her mandate is over. The politically exposed person would be tempted to replace it with a more luxurious property, yet a luxurious life would be only a dream unless the money gained from corruption cannot be made to appear as legal income. This creates the need to launder this money. 


\section{LAUNDERING MONEY ACQUIRED FROM CORRUPTION}

Money laundering itself can take different forms depending on the nature of the corruption practice (Barone et al., 2019, p. 4). A large number of corruption cases include receiving cash payments. This determines also how the money will be handled, since it has to be kept away until it is laundered. "The ability to transfer and conceal funds is critical to the perpetrators of corruption, especially large-scale or "grand corruption" (UNODC, 2004, p. 21).

The money laundering process is widely described as consisting of three phases - placement, layering, and integration. During the placement phase, money received from criminal activity is introduced into the financial system. Most often, legal financial institutions are used for this by making cash deposits to bank accounts, buying investment instruments and others. Following the first phase, once the money is already in the financial system, it goes through various transactions and operations so that it is no longer traceable to the original source. The layering of operations is needed as it makes it more difficult to trace and detect the illegal origin of the money. In the last third phase, money can be integrated into the legal economy with less risk of being detected. The possibilities for integration are numerous - investments in the capital market, purchasing real estate, purchasing luxury goods, cars, jewelry and much more. The money laundering process does not always go through all three phases, i.e. money can be laundered through only one of these phases (Van Duyne, 2003, p. 85). For example, when integration takes place through purchases of real estate or cars, the corrupt officials and the sellers formally finalize the deal at a much lower value than the real price of the property, and the rest is paid in cash with money whose origin does not need verification. Such agreements often take place in countries such as Bulgaria, where cash payments predominate and public acceptance of such practices is high.

In some cases, the money, especially from large-scale corruption cases, is transferred directly to a bank account specified by the corrupt person. Here, the placement phase is completed as soon as the money is received. Afterwards layering can be done through transfers to other accounts, using the money for bank guarantees to take loans, etc.

But corrupt practices do not always involve money. Corruption is also the act of transferring the ownership of a business to an intermediary or providing the use of property and services free of charge. Money laundering schemes are numerous and are limited only by the imagination and the capital (financial and social) of the corrupt employee.

\section{LIAISONS BETWEEN CORRUPTION AND MONEY LAUNDERING}

The links between corruption and money laundering can take different forms and all of them are important. In the previous section we discussed the most obvious link to corruption as a predicate crime to money laundering. Due to the enormous potential of corruption and the need to legalize the profits it generates, experts (FATF, 2012, p. 19) identify those who hold or have held senior political positions, as well as their associates, as a particularly high-risk group for corruption and related money laundering. Once laundered, money gained from corruption can be used for any purpose and gives great economic power to their owners.

On the other hand, corruption can take place in the very process of "dirty money" entering the legal financial system. Perpetrators bribe officers in the financial institutions to "circumvent" anti-money laundering requirements. Corruption, used to prevent the criminal nature of money 
from being exposed, reduces the effectiveness of anti-money laundering measures. This increases the vulnerability of the financial system to the inflow of money generated by organized criminal groups and even terrorist organizations (Livescu, 2017).

It could be stated that the connection between corruption and money laundering leads to development of deviant societies and the criminalization of the state (Petrunov, 2010). The two crimes have become so interlinked that it is difficult to distinguish between them (Mugarura, 2016). Moreover, corruption triggers money laundering, and vice versa, so that they mutually reinforce each other. The close links between corruption and money laundering suggests that policies designed to combat both crimes at the same time will be more effective.

\section{COUNTERACTION POLICIES}

Corruption is a difficult crime to detect and when it comes to prominent political figures, especially while they are in power, detection and investigation become even more complicated. This is usually a carefully planned, quickly executed, one-off act, and therefore, hard to investigate. The motivations of corrupt people, as we have already argued, are not only the financial gains, but also the possibility to enter the money in the legal economy. Thus, money laundering provides an additional opportunity for investigators to gather key evidence against corrupt individuals.

Despite that, as some authors have argued (Shehu, 2005), there has been a lack of consensus among the international institutions responsible for developing key documents and recommendations to combat both crimes on the benefits of using anti-money laundering regimes in the fight against corruption. In this regard, measures from all three main pillars aimed at countering money laundering have a key role to play: preventive measures can be of great benefit in stopping the profits from corruption to enter the legal economy; criminal law measures provide an important tool for investigators to reach to the top levels in the corrupt organizations and capture the most important actors by "following the money trail"; the confiscation of the illegally acquired assets (under civil or criminal law) deprives the corrupt perpetrators of their profits, which is the main motive for committing the crimes. Authors (Sharman, 2011, p. 176) who support such ideas also argue for the use of anti-money laundering measures in the fight against corruption.

Although corruption and money laundering are different phenomena related to specific problems, researchers (Chaikin \& Sharman, 2009, p. 7) argue that we can and, in fact, need to develop an integrated response, considering the actual link between corruption and money laundering. An effective anti-money laundering framework limits the channels through which illegal money can be laundered, making crime riskier and thus reducing the incentives for corrupt activities (Fontana \& Pereira, 2012). By shedding light on suspicious financial transactions in general, anti-money laundering mechanisms can help anti-corruption investigators detect both the illicit financial profits from corruption and the corruption schemes themselves. As other authors have noted (Fontana \& Pereira, 2012, p.1), this does not suggest that anti-money laundering mechanisms can or should replace the wide range of available anticorruption tools. Rather, they should be added to the existing ones. In order for this to happen, all the measures and procedures required by anti-money laundering policies need to be properly implemented and introduced in all sectors.

Recognizing the important role of anti-money laundering measures in the fight against corruption, the Egmont Group (2018) has proposed 55 specific indicators, the purpose of which is to facilitate the work of reporting entities to identify suspicious transactions and activities 
indicative of corruption. The same indicators could alert investigators of money laundering linked to corruption, and can therefore be used alone or in combination with other indicators or relevant information to improve the prosecution of the crimes. Particular attention is paid to PEPs, as they are at increased risk of corruption.

The more effective the fight against money laundering, the more productive the fight against corruption will be (UNODC, 2004, p. 29). The implementation of anti-money laundering measures can make a significant contribution to detecting corruption and can enable more efficient financial investigations. Therefore, we need policies that effectively integrate the counteraction against the two criminal activities.

\section{CONCLUSION}

As separate crimes, corruption and money laundering each have a strong negative impact on every social sphere. Combined, their strength increases, on the one hand. On the other hand, their interconnection gives perpetrators the possibility to conceal their dealings. Therefore, it is of utmost importance that the dangerous links between corruption and money laundering are given special attention by the institutions leading the fight against them, and new tools are created to counteract the criminal phenomena.

The more effective the anti-money laundering regime, the better results can be achieved in the fight against corruption. The negative consequences of money laundering and corruption extend to every sphere of society, but have a particularly strong impact on the financial integrity and stability of the state - undermining the trust in the institutions and creating favorable conditions for criminals, as criminals work best in weak and corrupt countries, where the money laundering controls are ineffective. It is therefore important for each country to develop policies to combat the two criminal phenomena, in order to secure a policy and social climate that does not facilitate but prevents and impedes corruption and money laundering.

\section{ACKNOWLEDGMENT}

This paper is result of the author’s work in frame of research project № NID NI-10/2018 financed by University of National and World Economy, Sofia.

\section{REFERENCES}

Argandoña, A. (2003). Private-to-private Corruption. Journal of Business Ethics, 47(3), 25367. https://doi: 10.2139/ssrn.685864.

Barone, R., Masciandaro, D., \& Schneider, F. (2019). Money laundering and corruption: Birds of a feather flock together. SSRN Electronic Journal. https://doi: 10.2139/ssrn.3400674.

Chaikin, D., \& Sharman J.C. (2009). The Corruption-Money Laundering Nexus. In Corruption and Money Laundering. Palgrave Series on Asian Governance (pp. 7-30). New York: Palgrave Macmillan. https://doi.org/10.1057/9780230622456_2.

Egmont Group. (2018). Set of Indicators for Corruption Related Cases from the FIUs Perspective. Available at: https://egmontgroup.org/en/content/new-publication-setindicators-corruption-related-cases-fius-perspective.

FATF. (2012). Specific Risk Factors in Laundering the Proceeds of Corruption. Paris: FATF. Fontana, A. \& Pereira, P.G. (2012). Using money laundering investigations to fight corruption in developing countries. Anti-Corruption Research Center. 
Gopinath, C. (2008). Recognizing and Justifying Private Corruption. Journal of Business Ethics, 82(3), 747-754. https://doi: 10.1007/s10551-007-9589-8.

Levi, M., Dakolias, M., \& Greenberg, T.S. (2007). Money Laundering, the Highway of Grand Corruption. In E.J. Campos \& S. Pradhan (Eds.), The Many Faces of Corruption (pp. 389-426). Washington, D.C.: The International Bank for Reconstruction and Development/The World Bank. https://doi: 10.1596/978-0-8213-6725-4.

Livescu, I. (2017). The link between Money Laundering and Corruption Is the fight effective? A thesis submitted in partial fulfillment of the requirements for the degree of Masters in European Union Law awarded by the Tilburg University Law School, Tilburg, The Netherlands.

Maltz, M. (1985). Toward Defining Organized Crime. In H. Alexander \& G. Caiden (Eds.), The Politics and Economics of Organized Crime (pp. 82-95). Massachusetts/Toronto: Lexinton Books.

Medina, L., \& Schneider, F. (2018). Shadow Economies Around the World: What Did We Learn Over the Last 20 Years? IMF Working Paper African Department, WP/18/17.

Mugarura, N. (2016). Uncoupling the relationship between corruption and money laundering crimes. Journal of Financial Regulation and Compliance, 24 (1), 74-89.

Nonchev, A, (2019). State capture of the Post-socialist state: challenges to European integration. Research Papers of UNWE, 3, 203-213. (in Bulgarian).

Petrunov, G. (2010). Organized Crime and Corruption as a Part of the Genesis of Deviant Societies: On the Example of the Crime Case „Human Trafficking“. Sociological Problems, 42 (1-2): 334-349.

Sartor, M.A., \& Beamish, P.W. (2020). Private Sector Corruption, Public Sector Corruption and the Organizational Structure of Foreign Subsidiaries. Journal of Business Ethics, 167, 725-744. https://doi.org/10.1007/s10551-019-04148-1.

Sharman, J. C. (2011). The Money Laundry: Regulating Criminal Finance in the Global Economy. Ithaca, NY: Cornell University Press.

Shehu, A.Y. (2005). International initiatives against corruption and money laundering: an overview, Journal of Financial Crime, 12(3), 221-245. https://doi.org/10.1108/13590790510624828.

Stoyanov, A. (2018). Private sector corruption in Bulgaria. Sofia: CSD.

Stoyanov, A. \& Gerganov, A. (2019). State capture: from theory to piloting a measurement methodology. UNWE Yearbook, 2, 19-46.

Tanzi, V. (1998). Corruption around the world: causes, consequences, scope and cures. International Monetary Fund staff papers, 45, 559-594.

Quintanilla, P.B., Cummins-Tripodi, P., Marié, A, \& Mussio, E. (2018). The costs of corruption across the EU. The Greens/EFA Group in the European Parliament. Available at: efa.eu/files/assets/docs/the_costs_of_corruption_across_the_eu.pdf.

https://www.greens-

UN. (2015). Transforming our world: the 2030 Agenda for Sustainable Development. Available at: https://sustainabledevelopment.un.org/post2015/transformingourworld.

UNODC. (2004). The Global Programme Against Corruption: UN Anti-Corruption Toolkit. Available at: https://www.un.org/ruleoflaw/blog/document/the-global-programmeagainst-corruption-un-anti-corruption-toolkit/.

UNODC. (2018). UNCAC 15th Anniversary. Available at: https://www.unodc.org/unodc/corruption/.

Van Duyne, P. (2003). Money Laundering Policy: Fears and Facts. In P. Van Duyne, K. von Lampe \& J. L. Newell (Eds.). Criminal Finance and Organizing Crime in Europe (pp. 72-109). Nijmegen, Netherlands: Wolf Legal. 
World Bank. (2018). Combating Corruption. Available at: https://www.worldbank.org/en/topic/governance/brief/anti-corruption. 